\title{
PKM KELOMPOK PENDIDIK SEBAYA DI SMA NEGERI 6 DEPOK
}

\author{
Diah Ratnawati', Tatiana Siregar ${ }^{2}$ \\ ${ }^{1}$ Program Studi Keperawatan, Fakultas Ilmu Kesehatan, Universitas Pembangunan Nasional Veteran Jakarta \\ Korespondensi: D. Ratnawati, ratnawatidiah@yahoo.co.id
}

\begin{abstract}
ABSTRAK
Program PKM Kelompok Pendidik Sebaya di SMA Negeri 6 Depok mengacu pada pendekatan, menggali suatu komunitas, dan metode yang dikembangkan dalam satu kelompok yang memiliki kedudukan sama antar anggota terutama berdasarkan umur, status atau kelas. Tujuan PKM, pendidik sebaya yaitu teman sebaya yang berperan dalam meningkatkan upaya pencegahan perilaku seks bebas yang dapat menyebabkan penyakit menular seksual termasuk HIVIAIDS pada remaja. Pembentukan dan pelatihan kelompok pendidik sebaya dilaksanakan selama 1 bulan. Kegiatan PKM ini berupa pembentukan kelompok konseling teman sebaya (2 kelompok dengan masingmasing berjumlah 15 orang), melakukan penyuluhan kesehatan tentang perilaku pacaran yang sehat dan penyakit HIV/AIDS bersama pendidik sebaya berupa pembinaan rutin sebanyak 8 kali pertemuan, melakukan kampanye Anti NAPZA, sekolah bebas asap rokok dan perilaku pacaran sehat, melaksanakan milieu terapi dengan pemasangan poster dan leaflet di lingkungan sekolah yang berisi himbauan untuk menghindari perilaku seks bebas yang mengakibatkan penularan HIV/AIDS, serta melatih terapi modalitas perilaku: kemampuan menolak ajakan teman sebaya dengan perilaku asertif. Evaluasi kegiatan PKM menggunakan kuesioner pre-test dan posttest. Hasil PKM ini berupa peningkatan pengetahuan, sikap, dan ketrampilan life skill dalam pencegahan perilaku seks bebas pada remaja serta mampu mendemonstrasikan terapi modalitas perilaku yang telah dilatih. Kelompok pendidik sebaya selanjutnya diberdayakan dalam membentuk konseling dalam penyelesaian masalah remaja dengan menggunakan aplikasi online berbasis IT.
\end{abstract}

Kata kunci: Pendidik Sebaya, Remaja, HIV/AIDS.

\section{PENDAHULUAN}

Pemerintah Kota Depok telah menetapkan program Usaha Kesehatan Sekolah (UKS) menjadi salah satu program strategis dalam rangka mewujudkan Kota Depok yang sehat, seperti yang tertuang dalam 9 prioritas pembangunan khususnya prioritas 7 dan 9 (Renstra Kota Depok, 2011). Program UKS tersebut dapat sukses dengan cara pemerintah Kota Depok melibatkan semua instansi pemerintahan di Kota Depok sampai tingkat Kelurahan. Komitmen ini dituangkan sejak tahun 2011 dalam Surat Keputusan Wali Kota tentang pembentukan Tim Pembina UKS tingkat Kota Depok dengan program prioritas UKS pada remaja usia sekolah SMA/SMK adalah Pelayanan Kesehatan Peduli Remaja/PKPR. Materi PKPR pada remaja usia SMA/SMK difokuskan pada upaya pencegahan penggunaan NAPZA, pencegahan perilaku seksual bebas, pencegahan penularan penyakit seksual menular termasuk didalamnya penularan HIV/AIDS (Kemenkes RI, 2014).

Hasil wawancara dengan Kasubag Kesehatan Keluarga Dinas Kesehatan Kota Depok tanggal 22 Januari 2018 terkait kesehatan remaja usia SMA/SMK bahwa telah tertuang Program UKS dan PKPR meliputi kegiatan penjaringan, pelatihan guru dan siswa, konseling dan pelayanan kesehatan remaja. Program PKPR telah dilakukan juga di tingkat Puskesmas terkait pencegahan risiko penularan penyakit seksual termasuk di dalamnya penyakit HIV/AIDS. Program PKPR dalam kegiatannya berupa upaya pencegahan penularan HIV/AIDS pada remaja sekolah mulai dari Dinas Kesehatan sampai Puskesmas belum dilaksanakan secara berkesinambungan, hanya dilakukan satu tahun sekali bersamaan dengan kegiatan orientasi siswa baru, bersifat insidental, dan belum merata pada semua sekolah di wilayah Puskesmas Limo. 
Berdasarkan hasil wawancara, hal tersebut disebabkan keterbatasan anggaran yang tersedia. Selain itu, program PKPR hanya bisa diakses oleh remaja dengan datang ke Puskesmas. Kemudian, alur PKPR dimulai dari pendaftaran, mengantri, dan mendapatkan layanan. Kondisi sekarang ini di Depok khususnya Kecamatan Limo belum semua Puskesmas PKPR memberikan pelayanan kepada remaja secara terpisah. Sebagian besar PKPR diberikan kepada remaja dengan digabungkan pada pelayanan umum. Waktu pelayanan di Puskesmas selalu bertepatan dengan jam sekolah.

Oleh karena itu, remaja yang masih bersekolah mendapatkan kendala mengakses terkait waktu pelayanan. Memang sudah ada beberapa Puskesmas yang menggunakan layanan konseling lewat alat komunikasi seperti situs website, aplikasi android maupun media sosial online lainnya, dan dapat membuat "janjian" untuk mendapatkan layanan. Namun, kendalanya malah remaja merasa kurang bisa bertanya hal-hal yang sifatnya privasi.

ika remaja tidak dilayani kebutuhan kesehatannya maka akan terjadi peningkatan masalah kesehatan karena remaja mengadopsi perilaku hidup yang tidak sehat seperti perilaku seks bebas dengan banyak pasangan atau pasangan berganti-ganti, pasangan sesama jenis, seks pranikah, hidup bersama, serta penyalahgunaan narkoba. Perilaku remaja tersebut membahayakan bagi kesehatan reproduksi dan mengakibatkan penyakit menular seksual termasuk HIV (Human Immunodeficiency Virus)/AIDS (Acquerid Immuno Deficiency Syndrome). Penyakit HIV/AIDS telah menyebar luas di hampir seluruh bagian dunia.

Data dari WHO/UNAIDS (2009) mengungkapkan bahwa penyebaran HIV/ AIDS terjadi secara endemi dan jumlah penderita HIV/AIDS meningkat secara tajam, sekitar 33.4 juta orang dengan estimasi 31.1-35.8 juta orang mengidap HIV/AIDS, munculnya infeksi baru 2.7 juta orang dengan estimasi 2.4-3.0 juta orang, dan kejadian kematian berjumlah 2 juta orang dengan estimasi 1.7-2.4 juta orang. Berdasarkan data tersebut, sekitar $80 \%$ penderita HIV/AIDS merupakan kelompok usia muda yaitu remaja. Hal tersebut menjadi dasar bagi remaja sebagai target utama dalam program pencegahan perilaku seks bebas yang dapat mengakibatkan penularan HIV/ AIDS (Soetjiningsih, 2007). Perilaku seks bebas dapat menimbulkan kehamilan yang tidak diinginkan dan narkoba yang menyebabkan kematian akibat overdosis tetapi sebelum itu terjadi remaja menjadi berisiko yang tinggi dalam penularan HIV/AIDS (Sulaiman, 2007).

Berdasarkan penelitian Allen, Hape, dan Miga (2008, dalam Dewi \& Wiarsih, 2012) tentang perilaku remaja, dari 184 sampel yang telah dilakukan wawancara pada remaja yang berusia 13 sampai 20 tahun terdapat hasil bahwa anak remaja sangat dipengaruhi oleh teman sebaya. Teman sebaya dapat mendorong remaja untuk berperilaku negatif seperti: menonton seks dari televisi, internet, majalah, dan compact disc/CD (Okanegara, 2008). Maka dari itu, pendidikan kelompok sebaya diyakini efektif digunakan sebagai pendekatan pada remaja karena dalam pelaksanaannya sesuai dengan karakteristik tumbuh kembang remaja yaitu kuatnya ikatan sebaya diantara mereka.

Pendidik sebaya adalah seseorang yang peduli dengan teman sebayanya diberi pengetahuan dan keterampilan untuk mengajarkan pengetahuan dan keterampilan kepada teman sebayanya (Lezin, 2010). Pembentukan pendidik sebaya merupakan salah satu bentuk pemberdayaan (empowerment) dalam strategi praktek keperawatan komunitas. Pemberdayaan pendidik sebaya diharapkan lebih mandiri sehingga dapat mengatasi keterbatasan sumber daya manusia (SDM) petugas kesehatan. Pemberdayaan pendidik sebaya yang dirancang oleh penulis dalam 
pengabdian masyarakat ini berdasarkan perpaduan teori comprehensive school health models dan family centre nursing.

Teori di atas digunakan sebagai dasar dalam pengembangan kerangka kerja (framework) untuk aplikasi model campuran pada upaya pencegahan risiko penularan infeksi HIV pada remaja berbasis sekolah khususnya SMA. Sekolah SMA Negeri 6 Depok dipilih sebagai tempat penyuksesan program PKPR dengan pembentukan kelompok pendidik sebaya karena beberapa alasan; pertama, lebih dari $70 \%$ remaja berada di tempat sekolah dan sebagian besar waktu digunakan di dalam lingkungan sekolah serta sangat memungkinkan bisa terbentuk pendidik sebaya ditunjang dengan peringkat akreditasi A. Kedua, SMAN 6 Depok dengan jumlah siswa sebanyak 1062 orang merupakan tempat berkumpul remaja laki-laki dan perempuan sangat mungkin dijadikan sebagai inisiatif awal untuk timbulnya perilaku seksual aktif pada usia sekolah.

Ketiga, SMAN 6 Depok terdapat 67 orang guru dan 27 kelas merupakan tempat yang penting untuk memulai program upaya pencegahan terhadap perilaku seksual dan perilaku berisiko lainnya yang lebih efektif dalam menurunkan infeksi seksual menular termasuk HIV. Terakhir, SMAN 6 Depok sebagai lembaga pendidikan yang beralamat di Jl. Raya Limo No. 30 Kec. Limo - Depok, Jawa Barat berjarak 9,0 km dari kampus UPN "Veteran " Jakarta sehingga sangat dekat dan kondusif sebagai tempat upaya penerapan kelompok pendidik sebaya dalam pencegahan penularan HIV/AIDS. Hasil focus group discussion/FGD yang dilakukan pada SMA Negeri 6 Depok didapatkan data 30,5\% pengetahuan tentang perilaku seks bebas dalam kategori kurang, 59,4\% remaja memiliki sikap negatif terhadap penyakit HIV/AIDS, 62,5\% remaja memiliki ketrampilan life skill kurang dalam menghadapi masalah perilaku seks bebas yang berisiko terhadap penularan HIV, dan 37,5\% remaja tinggal dalam lingkungan yang kurang kondusif dan berisiko untuk terjadinya perilaku seks bebas yang menyebabkan HIV/AIDS.

Selain itu, perilaku berisiko yang pernah dilakukan oleh remaja antara lain; 5,6\% remaja merokok, $1,2 \%$ minum alkohol, $15,6 \%$ pacaran pada malam hari, 10,2\% pernah berciuman, $8,9 \%$ pernah melihat gambar atau film pornografi, dan 7,8\% bolos atau tidak masuk sekolah. Perilaku tidak sehat remaja tersebut terjadi akibat perubahan fisik dan emosional dari remaja yang dipengaruhi lingkungan sekitarnya. Lingkungan yang paling berpengaruh pada remaja usia Sekolah Menengah Atas/SMA adalah sekolah.

Fenomena yang terlihat dari uraian diatas membuat sekolah sebagai tempat yang tepat untuk dilakukan program PKPR bagi remaja. Remaja berada di sekolah selama kurang lebih tujuh dalam sehari. Waktu yang banyak dihabiskan remaja di sekolah berpengaruh besar bagi perkembangan jiwa remaja (Sarwono, 2007). Di sekolah, remaja harus diberikan promosi kesehatan tentang pengetahuan dan keterampilan hidup sehat agar terhindar dari perilaku seks bebas maupun penularan HIV/ AIDS.

Promosi kesehatan biasanya berisi materi atau pesan yang disampaikan, alat bantu atau alat peraga pendidik yang dipakai, metode yang digunakan serta pendidik atau petugas yang melakukan promosi kesehatan (Notoatmodjo, 2007). Salah satu strategi promosi kesehatan dalam pencegahan perilaku seks bebas pada remaja berupa pemberdayaan remaja melalui pembentukan kelompok pendidik sebaya. 
Tujuan dibentuknya pendidik sebaya yaitu meningkatkan kesadaran dan tanggungjawab remaja terhadap perilaku seksual yang lebih sehat yang ditunjukkan dengan meningkatnya pengetahuan, sikap, dan perilaku terhadap upaya pencegahan perilaku seks bebas yang dapat menyebabkan penyakit menular seksual termasuk HIV/AIDS. Pembentukan pendidik sebaya ini ditujukan dari, oleh, dan untuk remaja sehingga pelayanannya dapat dilakukan dalam suatu peer group education remaja (WHO, 2002 dalam UNPFA, 2009). Pendidik sebaya dimotivasi untuk lebih banyak berinteraksi dengan teman sebaya agar dapat mempengaruhi teman sebayanya untuk mengubah perilaku sesuai yang diharapkan oleh pendidik sebaya.

Oleh sebab itu, perlu dilaksanakan program promosi kesehatan remaja dengan strategi kelompok pendidik sebaya di SMA Negeri 6 Depok. Kelompok tersebut melakukan kegiatan pelatihan penanganan dan pencegahan kepada guru dan siswa yang difasilitatori oleh dosen Program Studi Ilmu Keperawatan FIKES UPN "Veteran” Jakarta.

\section{METODE PELAKSANAAN}

Tempat dan Waktu. Kegiatan PKM Kelompok Pendidik Sebaya di SMA Negeri 6 Depok ini dilaksanakan sejak bulan Agustus 2018. Lokasi tersebut dikarenakan masih kurangnya pengetahuan dan ketrampilan life skill remaja dalam pencegahan perilaku seks bebas. Oleh karena itu, perlu dibentuk Kelompok Pendidik Sebaya untuk meningkatkan pengetahuan dan ketrampilan dalam pencegahan perilaku seks bebas pada remaja.

Khalayak Sasaran. Kegiatan PKM ini mengambil sebanyak 30 orang yang dibagi menjadi 2 kelompok pendidik sebaya.

Metode Pengabdian. Metode pelaksanaan kegiatan PKM ini berupa suatu program yang berisi sosialisasi, penyuluhan, dan pelatihan kepada remaja sebagai pendidik sebaya tentang upaya pencegahan terhadap perilaku seksual dan perilaku berisiko lainnya yang lebih efektif dalam menurunkan infeksi seksual menular termasuk HIV pada kelompok masyarakat yaitu siswa di SMA Negeri 6 Depok yang berisiko. Pengabdian masyarakat ini dilakukan melalui kemitraan dengan guru, siswa, dan SMA Negeri 6 Depok. Kegiatan PKM ini dilakukan melalui proses kelompok, dimulai dari pembentukan kelompok pendiidk sebaya yang diberikan pelatihan tentang remaja dan tumbuh kembangnya, kesehatan reproduksi, NAPZA, penyakit menular seksual, HIV/AIDS, ketrampilan life skill remaja dalam pencegahan perilaku seks bebas, dan dilatih teknik pendidikan kesehatan serta konseling pada teman sebayanya. Mitra diharapkan berperan aktif dalam setiap tahapan kegiatan sebagai pendidik ataupun sebagai peserta didik. Pada tahap awal kegiatan, mitra diharapkan menjadi informan ketika survei dan FGD tentang situasi sehingga diperlukan PKM ini. Lalu tahap pelaksanaan berupa kegiatan sosialisasi, penyuluhan dan pelatihan maka mitra diharapkan menjadi sebagai peserta didik yang mendapat transfer informasi maupun skill dari pengusul abdimas. Tahap akhir, mitra diharapkan sudah mampu menjadi pendidik sebaya dalam mencegah perilaku seks bebas dengan pendampingan dari pengusul abdimas sampai mitra dapat mandiri dalam melakukan kegiatan pendidik sebaya.

Indikator Pencapaian. Program PKM ini bertujuan untuk meningkatkan kemampuan kelompok pendidik sebaya dalam melakukan pencegahan perilaku seks bebas yang mengakibatkan penularan HIV/AIDS. Program ini sebagai upaya membina kelompok pendidik sebaya, teman sebaya dan kelompok konseling teman sebaya. Target pelaksanaan program adalah terjadi transfer of knowledge dan transfer of skill dari tim pelaksana PKM sebagai narasumber yang mendukung kelompok pendidik sebaya di SMA Negeri 6 Depok. Pengabdian masyarakat ini berfungsi untuk meningkatkan pengetahuan, sikap dan ketrampilan life skill 
pada kelompok pendidik sebaya dan teman sebaya berisiko dalam upaya pencegahan perilaku seks bebas yang mengakibatkan penularan HIV/AIDS, mempertahankan persepsi positif dan komitmen $100 \%$ remaja dalam upaya pencegahan HIV/AIDS, dan melaksanakan pembinaan dan upaya promosi kesehatan di sekolah sesuai dengan hasil pemeriksaan fisik melalui pre and post test dan demonstrasi-redemonstrasi pendidikan kesehatan maupun konseling pada remaja. Hasil PKM akan dipublikasikan dalam bentuk buku panduan kelompok pendidik sebaya di SMA Negeri 6 Depok dan jurnal penelitian berstandar Nasional (ISSN).

Evaluasi Kegiatan. Evaluasi dilakukan terhadap komitmen kelompok pendidik sebaya dan persentase remaja yang mendukung kegiatan pendidik sebaya serta ada atau tidaknya kesepakatan dengan pihak sekolah untuk upaya pembinaan berkelanjutan terkait pencegahan perilaku seks bebas pada remaja di SMA Negeri 6 Depok. Pelaksanaan milieu terapi terpasangnya poster dan leaflet di lingkungan sekolah yang berisi ajakan untuk menghindari perilaku seks bebas yang mengakibatkan penularan HIV/ AIDS. Selain itu, dengan alat ukur berupa kuesioner pada pre-intervention dan post-intervention tentang penerapan kelompok pendidik sebaya terhadap variabel pengetahuan dan variabel ketrampilan life skill yang diukur secara kuantitatif dengan analisa univariat maupun bivariat. Keberlanjutan kelompok pendidik sebaya dilakukan dengan penetapan struktur organisasi pendidik sebaya sebagai bagian program UKS dengan bantuan pembinaan dari tenaga kesehatan Puskesmas Limo Depok.

Kerja Sama Lintas Sektoral. Kerjasama lintas sektoral berbentuk kemitraan dengan SMA Negeri 6 Depok sebagai tempat PKM dan mitra aktif pada setiap tahapan PKM Kelompok Pendidik Sebaya ini.

\section{HASIL DAN PEMBAHASAN}

Kegiatan PKM kelompok pendidik sebaya di SMA Negeri 6 Depok telah dilaksanakan selama 8 kali pertemuan di bulan Agustus 2018. Pada tahapan awal, pengabdi melakukan sosialisasi kegiatan PKM kepada Wakil Kepala Sekolah Bidang Kesiswaan tentang tujuan pengabdian masyarakat, topik bahasan dalam kegiatan, jadwal pertemuan sesuai proposal yang diajukan, dan mengidentifikasi karakteristik siswa yang direkrut sebagai pendidik sebaya. Pemilihan pendidik sebaya sebanyak 30 orang, dibagi dalam 2 kelompok menjadi 15 orang. Kemudian, pengabdi meninjau ruangan auditorium beserta alat-alat seperti papan tulis, LCD, sound system dan microphone yang dipakai untuk melakukan kegiatan PKM. Tahapan awal dapat dilihat pada gambar

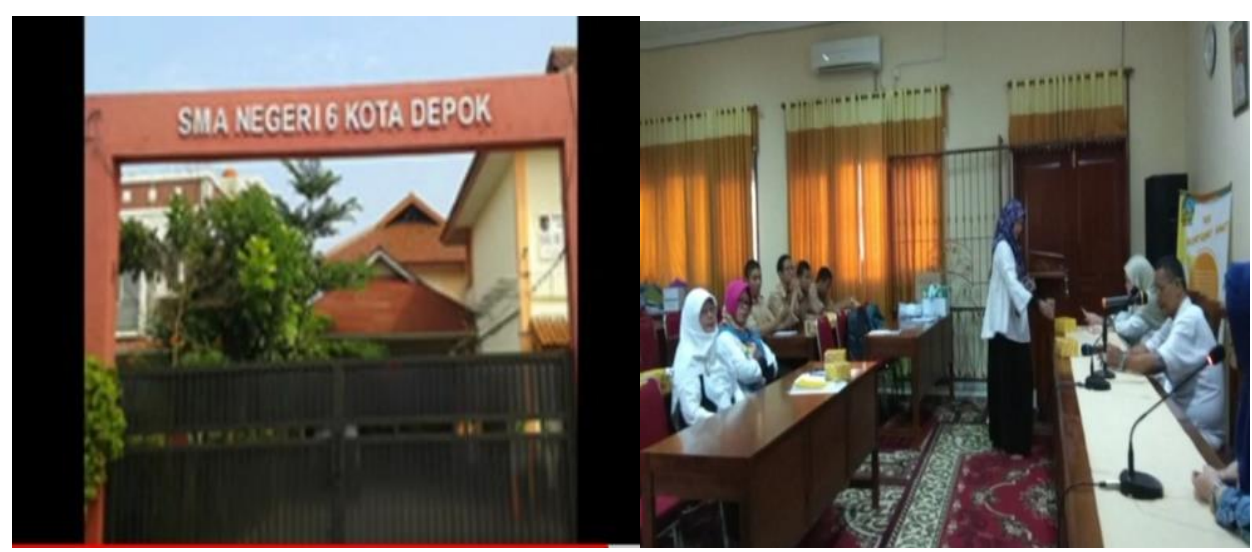

Gambar 1. Sosialisasi sebelum kegiatan PKM 
Sebelum pelaksanaan PKM, pengabdi juga mempersiapkan buku pelatihan dengan judul "Kelompok Pendidik Sebaya Dalam Pencegahan Perilaku Seks Bebas Yang Mengakibatkan Penularan HIV/AIDS". Buku pelatihan tersebut berisi tentang materi tentang pengetahuan, sikap dan perilaku pendidik sebaya. Saat pelaksanaan kegiatan PKM, pengabdi membagi kinerja tim sebagai berikut:

a. Penyuluh untuk materi dinamika kelompok, kesehatan reproduksi remaja, mengenal dan menanggulangi HIV/AIDS, remaja dan perilaku seksual, konseling remaja, serta peer educator: Ns. Diah Ratnawati, M. Kep., Sp. Kep. Kom.

b. Penyuluh untuk materi pertumbuhan dan perkembangan remaja, infeksi menular seksual, NAPZA, dan teknik pendidikan kesehatan: Ns. Tatiana Siregar, S. Kep., MM.

c. Pelaksanaan milieu terapi terpasangnya poster dan leaflet di lingkungan sekolah yang berisi ajakan untuk menghindari perilaku seks bebas yang mengakibatkan penularan HIV/ AIDS.

d. Praktek melakukan pendidikan kesehatan dan konseling kepada teman sebaya.

Hambatan yang dialami hanya berupa pendidik sebaya harus sering berlatih melakukan pendidikan kesehatan dan konseling kepada teman sebaya yang menghadapi masalah baik di rumah, sekolah, dan lingkungan masyarakat. Hasil PKM didapatkan hasil berupa umur dan jenis kelamin adalah sebagai berikut:

Tabel 1. Distribusi Usia dan Jenis Kelamin Pada Kelompok Pendidik Sebaya Menurut PreTest Dan Post-Test Di SMA Negeri 6 Depok Tahun 2018

\begin{tabular}{lclc}
\hline \multicolumn{1}{c}{ Variabel } & $\mathrm{n}$ & $\%$ & $\mathrm{~N}$ \\
\hline Usia & & & \\
\hline 16 tahun & 5 & 16,7 & 30 \\
\hline 17 tahun & 18 & 60 & \\
\hline 18 tahun & 7 & 23,3 & \\
\hline $\begin{array}{l}\text { Jenis } \\
\text { Kelamin }\end{array}$ & & & \\
\hline Laki-laki & 26 & 86,7 & 30 \\
\hline Perempuan & 4 & 13,3 & \\
\hline
\end{tabular}

Berdasarkan tabel diatas menunjukan bahwa pendidik sebaya di SMA Negeri 6 Depok mayoritas berusia 17 tahun yaitu sebanyak 18 orang (60\%), sedangkan jenis kelamin sebagian besar laki-laki yaitu sebanyak 26 orang $(86,7 \%)$. Hasil yang dicapai pada kegiatan pengabdian ini adalah peningkatan pemahaman pendidik sebaya tentang pencegahan perilaku seks bebas yang mengakibatkan penularan HIV/AIDS. Sebelum kegiatan PKM dilakukan pre-test dapat dililihat pada gambar 2. Pemberian materi dalam kegiatan PKM dapat dilihat pada gambar 3. 


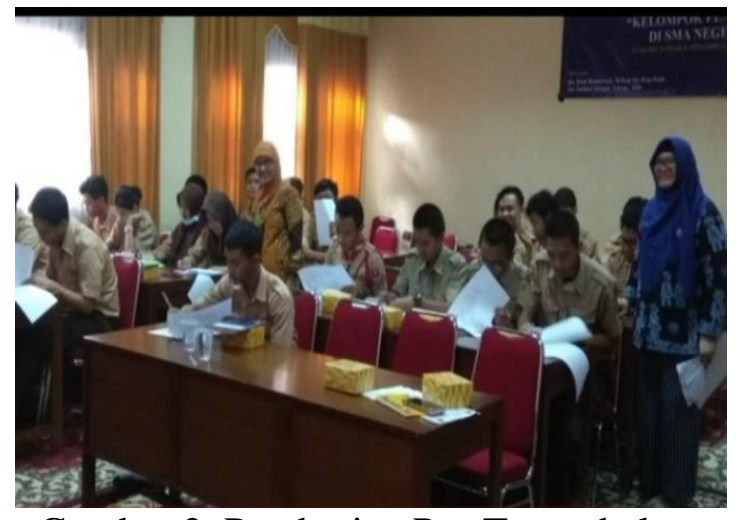

Gambar 2. Pemberian Pre-Test sebelum kegiatan PKM

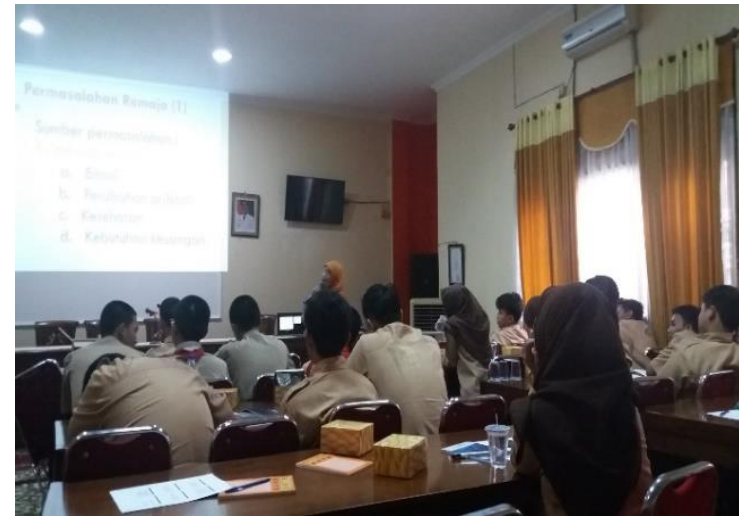

Gambar 3. Pemberian materi PKM

Selain itu, siswa sebagai pendidik sebaya juga diberikan pelatihan teknik pendidikan kesehatan dan konseling sehingga memiliki kemampuan menyelesikan masalah teman sebaya dengan dikoordinasi oleh guru dan Kepala Sekolah SMA Negeri 6 Depok. Pelatihan ini menggunakan kasus teman sebaya yang sesuai dengan kondisi remaja pada umumnya. Setiap peserta mencoba satu persatu dan akan dinilai kemampuannya. Kegiatan tersebut dapat dilihat pada gambar 4 dan 5 .

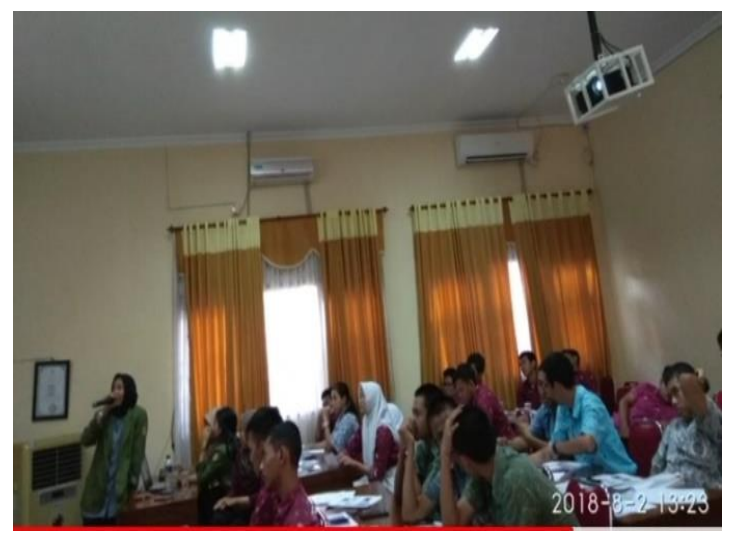

Gambar 4. Demonstrasi dan Redemonstrasi Teknik Pendidikan Kesehatan

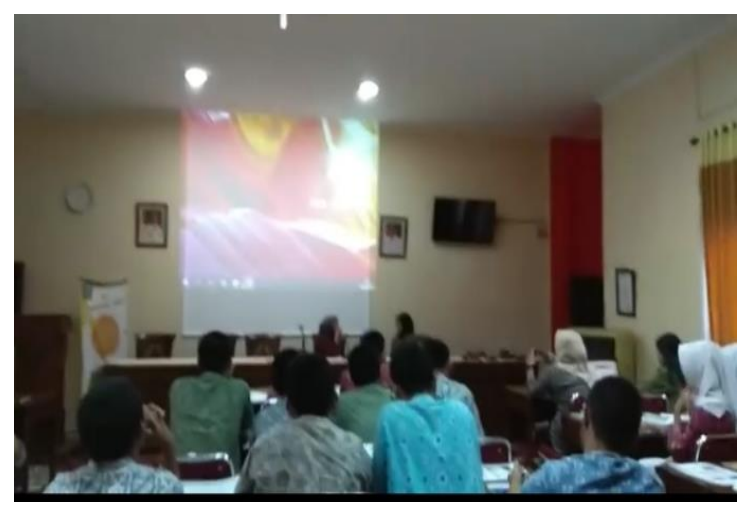

Gambar 5. Demonstrasi dan Redemonstrasi Konseling

Setelah dibentuk dan dilatih kelompok pendidk sebaya terdapat peningkatan pengetahuan, sikap, dan ketrampilan life skill pendidik sebaya tentang pencegahan perilaku seks bebas yang mengakibatkan penularan HIV/AIDS. Selain itu, terjadi peningkatan kemampuan psikomotor pendidik sebaya dalam melakukan terapi modifikasi perilaku, teknik pendidikan sebaya, dan konseling kepada teman sebaya maupun persepsi tentang pentingnya dukungan lingkungan disekitar remaja terhadap pencegahan perilaku seks bebas yang mengakibatkan penularan HIV/AIDS. Hal tersebut dapat dilihat pada tabel berikut :

Tabel 2. Distribusi Rata-Rata Pengetahuan Kelompok Pendidik Sebaya Menurut Pre-Test Dan Post-Test Di SMA Negeri 6 Depok Tahun 2018

\begin{tabular}{cccccc}
\hline Variabel & Mean & SD & SE & p-value & N \\
\hline Kel 1 & & & & & \\
\hline
\end{tabular}




\begin{tabular}{lccccc}
\hline $\begin{array}{l}\text { Pengetahuan } \\
\text { pre-test }\end{array}$ & 86,07 & 4.026 & 1,040 & 0.000 & 15 \\
\hline $\begin{array}{l}\text { Pengetahuan } \\
\text { post-test }\end{array}$ & 92,47 & 3.159 & 0.816 & & \\
\hline Kel 2 & & & & & \\
\hline $\begin{array}{l}\text { Pengetahuan } \\
\text { pre-test }\end{array}$ & 89,27 & 4,636 & 1,197 & 0.000 & 15 \\
\hline $\begin{array}{l}\text { Pengetahuan } \\
\text { post-test }\end{array}$ & 93,13 & 6,413 & 1,656 & & \\
\hline
\end{tabular}

Pada tabel 2 diatas menunjukkan rata-rata pengetahuan kelompok 1 pendidik sebaya pada pretest adalah 86,07 dengan standar deviasi 4,026; dan rata-rata pengetahuan kelompok 1 pendidik sebaya pada post-test adalah 92,47 dengan standar deviasi 3,159. Tabel 2 juga menunjukkan rata-rata pengetahuan kelompok 2 pendidik sebaya pada pre-test adalah 89,27 dengan standar deviasi 4,636; dan rata-rata pengetahuan kelompok 2 pendidik sebaya pada post-test adalah 93,13 dengan standar deviasi 6,413. Hasil uji statistik didapatkan p-value 0,000 maka dapat disimpulkan ada perbedaan yang signifikan antara pengetahuan pre-test dan post-test baik pada kelompok 1 maupun kelompok 2 pendidik sebaya.

Tabel 3. Distribusi Rata-Rata Sikap Kelompok Pendidik Sebaya Menurut Pre-Test Dan PostTest Di SMA Negeri 6 Depok Tahun 2018

\begin{tabular}{lccccc}
\hline Variabel & Mean & SD & SE & p-value & N \\
\hline \multicolumn{1}{c}{ Kel 1 } & & & & & \\
\hline $\begin{array}{l}\text { Sikap } \\
\text { pre-test }\end{array}$ & 47,40 & 5,552 & 1,434 & 0.005 & 15 \\
\hline $\begin{array}{l}\text { Sikap } \\
\text { post-test }\end{array}$ & 50,53 & 3,067 & 0.792 & & \\
\hline Kel 2 & & & & & \\
\hline $\begin{array}{l}\text { Sikap } \\
\text { pre-test }\end{array}$ & 40,07 & 5,561 & 1,436 & 0.000 & 15 \\
\hline $\begin{array}{l}\text { Sikap } \\
\text { post-test }\end{array}$ & 93,67 & 20,838 & 5,380 & & \\
\hline
\end{tabular}

Pada tabel 3 diatas menunjukkan rata-rata sikap kelompok 1 pendidik sebaya pada pre-test adalah 47,40 dengan standar deviasi 5,552; dan rata-rata sikap kelompok 1 pendidik sebaya pada post-test adalah 50,53 dengan standar deviasi 3,067. Tabel 3 juga menunjukkan rata-rata sikap kelompok 2 pendidik sebaya pada pre-test adalah 40,07 dengan standar deviasi 5,561; dan rata-rata sikap kelompok 2 pendidik sebaya pada post-test adalah 93,67 dengan standar deviasi 20,838. Hasil uji statistik didapatkan p-value 0,005 maka dapat disimpulkan ada perbedaan yang signifikan antara sikap pre-test dan post-test pada kelompok 1 dan p-value 0,000 maka dapat disimpulkan ada perbedaan yang signifikan antara sikap pre-test dan posttest pada kelompok 2 pendidik sebaya.

Tabel 4. Distribusi Rata-Rata Keterampilan Life Skill Menurut Pre-Test Dan Post-Test Di SMA Negeri 6 Depok Tahun 2018 


\begin{tabular}{llllll}
\hline \multicolumn{1}{c}{ Variabel } & Mean & SD & SE & p-value & N \\
\hline \multicolumn{1}{c}{ Kel 1 } & & & & & \\
\hline $\begin{array}{l}\text { Keterampilan } \\
\text { pre-test }\end{array}$ & 62,622 & 7,585 & 1,958 & 0.005 & 15 \\
\hline $\begin{array}{l}\text { Keterampilan } \\
\text { post-test }\end{array}$ & 68,088 & 5,211 & 1,345 & & \\
\hline Kel 2 & 61,267 & 10,185 & 2,630 & 0.000 & 15 \\
\hline $\begin{array}{l}\text { Keterampilan } \\
\text { pre-test }\end{array}$ & 67,155 & 7,567 & 1,953 & & \\
\hline $\begin{array}{l}\text { Keterampilan } \\
\text { post-test }\end{array}$ & & & & & \\
\hline
\end{tabular}

Pada tabel 4 diatas menunjukkan rata-rata keterampilan Life Skill kelompok 1 pendidik sebaya pada pre-test adalah 62,622 dengan standar deviasi 7,585; dan rata-rata keterampilan Life Skill kelompok 1 pendidik sebaya pada post-test adalah 68,088 dengan standar deviasi 5,211. Tabel 4 juga menunjukkan rata-rata keterampilan Life Skill kelompok 2 pendidik sebaya pada pre-test adalah 61,267 dengan standar deviasi 10,185; dan rata-rata keterampilan Life Skill kelompok 2 pendidik sebaya pada post-test adalah 67,155 dengan standar deviasi 7,567. Hasil uji statistik didapatkan p-value 0,000 maka dapat disimpulkan ada perbedaan yang signifikan antara keterampilan Life Skill pre-test dan post-test baik pada kelompok 1 maupun kelompok 2 pendidik sebaya

Tabel 5. Distribusi Rata-Rata Psikomotor Kelompok Pendidik Sebaya Menurut Pre-Test Dan Post-Test Di SMA Negeri 6 Depok Tahun 2018

\begin{tabular}{lccccc}
\hline \multicolumn{1}{c}{ Variabel } & Mean & SD & SE & p-value & N \\
\hline \multicolumn{1}{c}{ Kel 1 } & & & & & \\
\hline $\begin{array}{l}\text { Psikomotor } \\
\text { pre-test }\end{array}$ & 49,93 & 7,136 & 1,843 & 0.000 & 15 \\
\hline $\begin{array}{l}\text { Psikomotor } \\
\text { post-test }\end{array}$ & 58,93 & 3,863 & 0,997 & & \\
\hline Kel 2 & & & & & \\
\hline $\begin{array}{l}\text { Psikomotor } \\
\text { pre-test }\end{array}$ & 50,07 & 8,916 & 2,302 & 0.000 & 15 \\
\hline $\begin{array}{l}\text { Psikomotor } \\
\text { post-test }\end{array}$ & 98,40 & 16,801 & 4,338 & & \\
\hline
\end{tabular}

Pada tabel 5 diatas menunjukkan rata-rata psikomotor kelompok 1 pendidik sebaya pada pretest adalah 49,93 dengan standar deviasi 7,136; dan rata-rata psikomotor kelompok 1 pendidik sebaya pada post-test adalah 58,93 dengan standar deviasi 3,863. Tabel 5 juga menunjukkan rata-rata psikomotor kelompok 2 pendidik sebaya pada pre-test adalah 50,07 dengan standar deviasi 8,916; dan rata-rata psikomotor kelompok 2 pendidik sebaya pada post-test adalah 98,40 dengan standar deviasi 16,801. Hasil uji statistik didapatkan p-value 0,000 maka dapat disimpulkan ada perbedaan yang signifikan antara psikomotor pre-test dan post-test pada kelompok 1 dan kelompok 2 pendidik sebaya 
Tabel 6. Distribusi Rata-Rata Persepsi Kelompok Pendidik Sebaya Menurut Pre-Test Dan Post-Test Di SMA Negeri 6 Depok Tahun 2018

\begin{tabular}{llllll}
\hline Variabel & Mean & SD & SE & p-value & N \\
\hline \multicolumn{1}{c}{ Kel 1 } & & & & & \\
\hline $\begin{array}{l}\text { Persepsi } \\
\text { pre-test }\end{array}$ & 90,53 & 14,407 & 3,720 & 0.004 & 15 \\
\hline $\begin{array}{l}\text { Persepsi } \\
\text { post-test }\end{array}$ & 94,80 & 11,583 & 2,991 & & \\
\hline Kel 2 & & & & & \\
\hline $\begin{array}{l}\text { Persepsi } \\
\text { pre-test }\end{array}$ & 93,67 & 20,838 & 5,380 & 0.016 & 15 \\
\hline $\begin{array}{l}\text { Persepsi } \\
\text { post-test }\end{array}$ & 98,40 & 16,801 & 4,338 & & \\
\hline
\end{tabular}

Pada tabel 6 diatas menunjukkan rata-rata persepsi kelompok 1 pendidik sebaya pada pre-test adalah 90,53 dengan standar deviasi 14,407; dan rata-rata persepsi kelompok 1 pendidik sebaya pada post-test adalah 94,80 dengan standar deviasi 11,583. Tabel 6 juga menunjukkan rata-rata persepsi kelompok 2 pendidik sebaya pada pre-test adalah 93,67 dengan standar deviasi 20,838; dan rata-rata persepsi kelompok 2 pendidik sebaya pada post-test adalah 98,40 dengan standar deviasi 16,801. Hasil uji statistik didapatkan p-value 0,004 maka dapat disimpulkan ada perbedaan yang signifikan antara persepsi pre-test dan post-test pada kelompok 1 dan p-value 0,016 maka dapat disimpulkan ada perbedaan yang signifikan antara persepsi pre-test dan posttest pada kelompok 2 pendidik sebaya.

Kegiatan ini sangat dirasakan manfaatnya oleh siswa dan guru di SMA Negeri 6 Depok sehingga dapat memberikan solusi terhadap masalah kesehatan remaja melalui pendidik sebaya yang memberikan pendidikan kesehatan dan konseling kepada teman sebayanya. Kegiatan ini pun sangat didukung oleh pihak SMA Negeri 6 Depok dan dan Puskesmas Kecamatan Limo Depok Jawa Barat sehingga program ini sangat cepat direspon untuk mendukung program PKPR Kota Depok.

\section{KESIMPULAN}

Kegiatan PKM kelompok pendidik di SMA Negeri 6 Depok pada kedua kelompok yang telah dibentuk sudah sampai pada tahapan evaluasi. Proses evaluasi tersebut dilaksanakan selama 3 bulan menunjukkan mayoritas pendidik berusia 17 tahun, berjenis kelamin laki-laki dan peningkatan pengetahuan, sikap, psikomotor, persepsi dan perilaku terjadi pada saat akhir kegiatan.

\section{Ucapan Terima Kasih}

Penulis mengucapkan terima kasih kepada SMA Negeri 6 Depok dan Puskesmas Kecamatan Limo Depok Jawa Barat yang telah memberi kesempatan pada kami dalam melakukan kegiatan ini, serta mahasiswa-mahasiswa Universitas Pembangunan Nasional Veteran Jakarta yang turut serta dalam membantu berlangsungnya kegiatan ini.

\section{REFERENSI}


Dewi, A.P. \& Wiarsih, W. (2012). Penerapan Metode Peer Edukasi Dalam Pencegahan Perilaku Seksual Pra Nikah Pada Remaja di Kelurahan Pasir Gunung Selatan, Depok. Jurnal Keperawatan Stikes Hang Tuah Tanjung Pinang, Volume 2, Nomor 2, Hal 154165.

Kemenkes RI. (2014). Pedoman Standar Nasional Pelayanan Kesehatan Peduli Remaja (PKPR). Diakses dari https://kupdf.com/download/ped-standar-nas pkpr_589da0e06454a7ce38b1e913_pdf pada tanggal 31 Januari 2018.

Lezin, Nicole. (2010). Peer Education in Teen Pregnancy Prevention With a Little Help From My Friends: Peer Education in Teen Pregnancy Prevention. California. Ressources center for Adolescents Pregnancy Preventif.

Notoatmodjo. (2007). Promosi Kesehatan \& Ilmu Perilaku. Jakarta: Rineka Cipta

Okanegara, K. (2008). Sexuality Reproductive Health Youth. Diakses dari http://okanegara.com/daily pada tanggal 31 Januari 2018

Renstra Kota Depok. (2011). Rencana Pembangunan Jangka Menengah Daerah Kota Depok Tahun 2011-2016. Diakses dari http://bappeda.depok.go.id/files_downloads/1RPJMD\%202011-2016.pdf pada tanggal 31 Januari 2018.

Sarwono, Sarlito Wirawan. (2007). Psikologi Remaja. Jakarta: PT. Raja Grafindo Persada.

Sulaiman, Zen. (2007). Konsep Bimbingan Dan Konseling Di Sekolah. http://farhanzen.wordpress.com/. Diperoleh tanggal 31 Januari 2018

Soetjiningsih. (2007). Tumbuh Kembang Remaja dan Permasalahannya. Jakarta: Sagung Seto.

UNPFA. (2009). Adolescent Sexual and Reproductive Health Toolkit For Humanitarian Settings: A Companion to The Interagency Field Manual on Reproductive Health in Humanatarian Setting.

WHO/UNAIDS. (2009). AIDS Epidemic up date 2009. http://www.unaids.org/en/KnowledgeCentre/HIVData/EpiUpdate/EpiUpdArchive/2009/ default.asp. Diperoleh tanggal 31 Januari 2018 